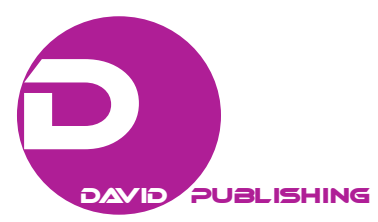

\title{
Tourism in Turkey: A Socio-Economic Assessment
}

\author{
Amer Al-Roubaie \\ Ahlia University, Manama, Bahrain
}

\begin{abstract}
Tourism plays an important role in socio-economic development of nations worldwide. In the case of poor countries, tourism contributes to job creation, poverty alleviation, and foreign exchange earnings. Because of its multi-discipline dimensions, tourism increases the economy capabilities to generate production linkages which encourage investments in various productive and service sectors of the economy. Countries with limited natural capital can benefit from tourism to sustain growth and support development. Turkey is one of the most attractive tourism destinations in the world. Because of its geographical location and cultural attractions, Turkey has become an important spot for millions of tourists from different parts of the world. The aim of this paper is to examine the impact of tourism on socio-economic development in Turkey and the future prospects that the country can achieve from investment in the tourism sector. Turkey should construct well-defined strategy the aim of which is to make tourism as an effective instrument for fostering economic growth and sustaining development.
\end{abstract}

Keywords: Turkey, tourism, linkages, development, globalization

\section{Introduction}

Tourism plays an important role in the socio-economic development of many nations worldwide. Recent advancement in information technology, transportation, and income per capita are expected to increase demand for tourist-related activities in the decades ahead making tourism an important driver for global development and growth. There are more people traveling today than ever before reflecting the changing attitude towards vacations abroad. While the aggregate number of people going abroad for leisure from wealthy countries continues to increase, tourism emanating from the developing world has been on the rise in recent times. By 2020 , the number of tourists in the world is expected to reach to nearly 1.6 billion. Being a popular destination for tourists, Turkey must pay heed to the regional and global changes impacting tourism and increase investment in the tourist infrastructure in order to stay competitive as a touristic destination.

Tourism stimulates market activities by creating linkages and generating demand for locally produced goods and services. Economic activities driven by tourists reduce income inequalities by opening up opportunities for lower and middle-income classes to participate in market activities. Tourism not only enhances productivity and cultivates tacit knowledge, but also increases economic diversification through the creation of new industries and services linked to the tourist sector. Recent literature on knowledge societies highlights the importance of creative enterprises and innovation in fostering economic growth and strengthening the fundamentals for building a knowledge economy. Tourism induces creative activities by encouraging the production and export of creative and knowledge-based products and services. These activities are influenced by traditional cultural features that distinguish different societies from one another. Turkey in

Amer Al-Roubaie, Ph.D. (McGill University)/professor, Ahlia University, Manama, Bahrain. 
particular is known for its unique cultural, geographical, and historical characteristics which stimulate the production and sale of creative products.

The aim of this paper is to discuss briefly the contribution of tourism to the socio-economic development of Turkey. Given its unique blend of natural, historical, and religious endowments, Turkey is an attractive destination for tourists both intra-regionally and internationally. The city of Konya, for example, constitutes a spiritual center of the Mevlana of Jalal al-Din Muhammad Rumi, commonly known as Mevlana. Every year, millions of tourists travel to Konya to witness a cultural and historical era identified with the teaching of a legendary figure in human history. This paper both examines the current economic impact of tourism on the economy and limns the future prospects of tourism as a key driver of the economic development of the country. The potential impact of tourism on the Turkish economy reflects the effectiveness of both local and national policies to stimulate investment in necessary infrastructure for the tourist industry. This paper recommends that Turkey should take advantage of its natural and cultural features and develop the tourist sector to increase linkage creation and strengthen the economic fundamentals.

\section{The Importance of Tourism}

Tourism plays an important role in fostering economic growth and enhancing the quality of life. When tourists spend money in the local economy, it increases aggregate demand generating spillover effects across various sectors in the economy. Tourism not only creates new jobs, but also provides new opportunities for small and medium enterprise to participate in the local economy. In many countries, touristic sites and natural attractions are located in rural communities and isolated areas which will benefit from the demand for goods and services by tourists as well as from building physical and technological infrastructure to accommodate the influx of tourists. This will motivate both local and foreign investors to take advantage of the creation of linkages and channel new investments into these communities. Under such circumstances, tourism could play an important role in preserving traditional culture and maintaining historical heritage. Isolated communities will also get exposure to the rest of the world via networking and media reporting increasing global awareness about the challenges facing them including poverty, underdevelopment, environmental degradation, resource exploitation, wildlife poaching, and human rights violations.

Globally, tourism represents one of the key drivers of the global economy. In 2015, 1.2 billion people travelled across the world representing one out every 12 persons employed. Tourism generated US $\$ 1,245$ billion or $9 \%$ of world GDP. In global exports, tourism represented about $6 \%$ of global exports of goods and 30\% of the world's exports of services with a total value of US\$1.409 billion in 2013. In 2014, total receipts from the international tourist industry accounted for about US\$1.5 trillion almost double of the amount in 1970. According to the global assessment report, the overall contribution of the travel and tourism sector to the global GDP reached US\$7.6 trillion in 2014. In 60 countries tourism constitutes the number one export earners while in 150 other countries it represents one of the five top export earners. The share of the Middle East in global revenues from tourism was estimated at US $\$ 49$ billion in 2014 reflecting the important economic potential that tourism can have on development in the region (World Tourism Organization, 2015).

Despite the global financial crisis and political uncertainty in different parts of the world, international travel has contributed positively to the global economy accounting for about 10\% to the global GDP in 2015 . Attracting tourists will require building tourist capacity comprising good physical infrastructure, efficient financial services, affordable communication and information systems, cheap health services and reliable 
transportation networks. Such infrastructure also supports development by increasing productivity and diversifying the economic structure. Thus, governments need to develop effective strategies to integrate the tourist sector into the national economic policy in order to stimulate linkages and create locally driven commercial and financial products and services. In poor areas where employment opportunities are lacking, tourism creates demand for jobs often filled by women and young people.

The socio-economic impact of tourism is largely identified with the income earned from tourists in return for services by local providers. According to the United Nations tourism generates income equivalent to a $\$ 3$ billion-a-day which benefits all nations if they attempt to invest in tourism. It also represents the main source of foreign exchange for a large number of both developed and developing countries (Creative Economy Report, 2010 , p. 21). The tourist industry creates linkages in the local economy which require drawing resources directly from within the domestic market creating in the process new opportunities, especially for women and low skilled workers.

Most businesses involved in the tourism sector are small- and medium-size enterprises which need financial and technical support to expand and contribute to the national economy. Tourism is a labor-intensive activity which demands a large number of people for providing the necessary services to meet tourist requirements. For countries suffering from high unemployment, the establishment of such industries offers not only the prospect of reducing unemployment, but also of alleviating poverty. It is well known that tourism draws more on locally supplied products and services than imported products. Product and service providers of tourism are usually produced through a chain of activities and inputs across several sectors of the economy. Such activities encourage linkage creation which increases the demand for domestically produced products and services. Demand by tourists not only induces local entrepreneurs to supply goods and services, but also opens up new opportunities, especially for poor people, to participate in the economy and become entrepreneurs.

There are wide range of linkages attributed to the tourist industry at micro, macro, and institutional levels. In particular, the least developed countries benefit directly and indirectly from the tourist industry not only in terms of job and income creation, but also in terms of the linkage effects of the tourist industry. In this regard, building tourist capacity contributes positively to the national development through poverty reduction, export growth, foreign exchange earnings, creating cultural industries, education and knowledge acquisition. Achieving such objectives will require policy makers to understand the relationship between development and tourism in order to enable them to identify the areas in which investments are needed for the creation of suitable tourist environment.

Unlike other sectors in the economy, tourism is a multidimensional activity driven by linkage creation and connection to several industries and services including food produce, manufactured products, communication, transportation, financial services, and several other goods and services.

One way to think about the economic impact of tourism would be to consider the international demand it generates within a developing country. Tourism creates a foreign, diversified source of demand within the borders of the host economy, breeding new supply opportunities for entrepreneurs. (Lejarraja \& Walkenhhorst, 2007, p. 3)

\section{Tourism in Turkey}

Turkey has been among the most attractive places among foreign tourists. During the period 2002 and 2014 , the number of foreign visitors to Turkey increased by $210 \%$ making the country among the most popular destinations for people from all over the world. Between 2003 and 2014 tourist income accounted for \$US34.3 
billion representing $4.3 \%$ of the country total GDP. In 2014, the number of tourists visited Turkey reached 39.8 million or by an increase of 5.3\% from the previous year. Whereas, income from exports "International receipts (exports) amounted to \$US37.4 billion, an increase of 6.7\% on 2013 (OECD, 2016). In addition to foreign visitors in Turkey, domestic tourism recorded 70.9 million people travelled in the country during 2014. However, the overall impact of travel and tourism sectors in Turkey, which represent both direct and indirect impacts, accounted for $\$ 96$ billion of the country's GDP in 2014 making the contribution of these sectors greater than many economic sectors in the economy. According to a recent report by the World Travel \& Tourism Council (WTTC) travel and tourism sectors' direct industry GDP in Turkey increased by 256\% between 1990 and 2014 compared to the increase in the total economy by 110\% (World Travel \& Tourism Council (WTTC), 2015).

Until recently, political developments in the Middle East have benefited Turkey's tourism sector. The Arab Spring creating instability in Egypt and Tunisia had created an opportunity for Turkey with foreign tourists redirecting travel to a perceived safe country in which to travel. In the last six months, however, the pendulum has swung against Turkey in the political plane. Internally, Islamic State and PKK terrorist acts have chipped away at Turkey's being perceived by tourists as a safe destination. In addition, the shooting down of a Russian SU-24 aircraft by the Turkish Air Force was regarded as a "planned provocation" by the Kremlin, which, in retaliation, enjoined Russian travel agencies from organizing tours to Turkey. Only Germany supplies a greater number of tourists to Turkey than Russia. The number of Russian tourists declined by $18 \%$ to 3.6 million in 2015 relative to 2014 impacting aggregate foreign travel to Turkey reducing the number of visitors to 36 million in 2015 compared to about 40 million in the previous year. In 2016, the Turkish Ministry of Tourism projects a loss of 4.5 million Russian tourists ${ }^{1}$. This drop in foreign visitors has caused revenues from tourism in Turkey to decrease from \$US34 billion to US\$31.5 billion in 2015 (ASIA Times News, February 25, 2016). In addition, returning refugees heading back from Europe to Turkey, pursuant to a political deal between EU and Turkey, have already sparked protests by Turks unwilling to accept Turkey's being transformed into a series of refugee camps ${ }^{2}$. A spike in civil strife in Turkey is likely to trigger a further decline in tourist numbers in 2016.

In its strategic plan for the period 2015-2019, the Turkish Ministry of Culture and Tourism outlines several objectives of tourism in Turkey the purpose of which are to enhance competitiveness, develop tourist activities all year round, and create a consistent, significant, and attractive brand for Turkey at international level (OECD, 2016). The Travel and Tourism Competitiveness Index 2015 ranks Turkey number 44 among the 141 countries included in the survey. The index measures the various policies that make a country attractive for foreign visitors. It also reflects the quality of services provided by the local tourist industry and the future potential and long term sustainability of tourism within the national economy (World Economic Forum, 2015). Key identified lag areas in a series of Travel \& Tourism Competitiveness Reports (2013-2015) include: safety and security issues (ranked 79th), inadequate ground transport infrastructure (exclusive of airports), laggard information and communication technology infrastructure (ranked 71st), and low environmental sustainability (ranked 95th) ${ }^{3}$. Of these, safety and security, after having started improving (2013-2014), are now deteriorating.

\footnotetext{
1 https://www.rt.com/business/329075-turkey-lose-russian-tourists/.

$2 \mathrm{http} / / / \mathrm{www}$.euronews.com/2016/04/02/turks-protest-plans-to-process-migrants-returned-under-eu-deal/.

${ }^{3}$ http://www.hurriyetdailynews.com/turkeys-tourism-ranks-46-out-of-140-countries.aspx?pageID=238\&nID=42635\&NewsCatID=349.
} 
Expenditures by tourists trigger strong multiplier effects which stimulate aggregate demand across the various sectors of the economy. At the local level, authorities in such places as Konya can take advantage of the flows of travelers to Turkey through public campaigns and provide better services to make it more attractive for tourists to visit the area. Tourism spans a wide range of activities. In recent years, cultural tourism, nurtured by government agencies, private enterprises, and international institutions, has grown in many countries. With its large potential, Turkey should encourage tourism by providing adequate facilities that make the tourist sector more competitive with best services provided by other countries. In recent years, the demand for travel has been on the rise increasing the prospect for more people to travel, especially to those countries with popular attractions including Turkey. Policy makers should take notice of such trends and make sure that the tourist sector receives adequate support to provide the necessary services for tourists. In other words, both local and federal governments should take advantage of the tourism potential and provide the necessary investment needed to develop the industry and encourage domestic enterprises to participate in such development. Turkey enjoys an excellent geographical position located between Europe and Asia and, in addition, it boasts attractive natural scenery and unique religious and historical sites of interest to people in both the East and the West.

Due to its high linkage spillovers, investment in tourism stimulates demand for touristic goods and services, ratchets up economic diversification, and increases productivity of the economy. Increases in productivity encourage exports of locally produced goods. In the case of Turkey, the ratio of tourism revenues to export revenues accounted for about one third in 2011 up from $21 \%$ in 2009. In contrast, during the same period, the ratio of tourism expenditures to import expenditures amounted to $3.7 \%$ and $2.9 \%$, respectively. In 2009 revenues from tourism in Turkey exceeded \$21 billion compared to $\$ 326.7$ million in 1980. This reflects the importance of tourism to the Turkish economy and underscores the potential that foreign tourists bring to bear on the future development of the country. In this age of global linkages and international interdependencies, countries such as Turkey could reap substantial economic benefits from tourism by investing in the tourist industry, enhancing security, maintaining political stability, and increasing national, regional, and global awareness.

In 2011, Turkey is ranked as the 6th most popular country visited by foreign visitors in the world. Among the European countries, Turkey is ranked number four reflecting the importance of the tourist sector in the overall development of the economy and the potential impact that tourism could play in fostering economic growth. Turkey received 31,456,076 visitors in 2011 compared to 8,000,000 in 2000 or at an increase of $293 \%$. Between 1995 and 2004, income from tourism in Turkey increased by $221 \%$ from $\$ 4,957$ million to $\$ 15,888$ million respectively. In 2004, tourism accounted for 5.3\% of GDP. Income from tourism in Turkey accounted for $\$ 23,020,392,250$. According to tourism statistics of Turkey, in the third quarter of 2012, income earned from tourism was $\$ 8,957,384,030,79.2 \%$ of which is from foreign tourists.

Tourism in Turkey represents diversified services which can provide a strong support for creating a creative economy capable of generating income and creating employment. Turkey is already a leading exporter of arts \& crafts. In 2008, Turkey's exports of these products accounted for $\$ 1,715$ million representing about $6 \%$ of the global share of arts \& crafts export. These exports grew at an average growth rate of $24.05 \%$ during 2003-2008 representing one of the highest growth rates among exporters.

Investment in the tourist sector enhances economic productivity through the creation of chain of services capable of generating linkages within the productive structure. Most services provided for tourists are locally produced facilitating economic growth, directly and indirectly, through the expansion of services provided for 
tourists. It is estimated that the direct contribution of tourism accounted for 4.1\% of the Turkish GDP in 2011, whereas, indirectly, tourism contributed another $3.9 \%$ to the GDP in the same year. Indirect contribution of tourism to GDP suggests that the tourist sector could have substantial potential to contribute to the overall development of the economy, given the implementation of appropriate investment policies to encourage tourism. According to the International Labour Organization (ILO) tourism created 253 million jobs worldwide in 2010. In Turkey, the tourism generated $8.1 \%$ of the total employment in 2011.

Because of its rich cultural and historical heritage and varied geography, Turkey will continue to draw tourists but, in 2016, the number of tourists will continue a downward slide after peaking in 2014. In recent months, Turkey has experienced substantial retrogression, both politically and economically, combining increasing economic instability with deterioration in national security, making the country less attractive as a tourist destination notwithstanding the location of Turkey as a bridge between Europe and Asia. This special geographical significance has been leveraged by the national air carrier Turkish Airlines rendering Istanbul an international air hub for huge numbers of transit passengers. In terms of annual revenues, Turkish Airlines currently ranks 24th in the world (2010) but regionally 5th largest in Europe and 2nd largest in the Middle East ${ }^{4}$.

\section{Tourism and the Creative Economy}

Recent literature on economics has discussed the emergence of a creative economy driven by the establishment of industries representing wider range of scientific and technological products. As pointed out by the United Nations,

Knowledge and creativity are becoming powerful drivers of economic growth in the contemporary globalizing world. They have profound implications for trade and development. Together with technology, they open up a huge potential for developing countries to develop new areas of wealth and employment creation consistent with the new trends in the global economy. For such countries to realize this potential, it is necessary to carefully formulate specific policies for enhancing creative capacities through strategic actions to be taken by governments at local, national and regional levels, while exploring possibilities for international cooperation and strategic alliance. (Creative Economy Report, 2010, p. 209)

Among the important elements that play a key role in the development of the creative economy is tourism.

The creative economy cuts across the arts, business and connectivity, driving innovation and new business models. The digital era unlocked marketing and distribution channels for music, digital animation, films, news, advertising, etc., thereby expanding the economic benefits of the creative economy. (Creative Economy Report, 2010, p. xxiv)

The building of a creative economy could benefit from the new information and communication technologies (ICTs) to promote creative industries and speed up the process of development.

Tourism encourages the production of creative industries through the use of crafts, production of cultural goods, arts, and music to attract more visitors to the country. Foreign visitors are interested in cultural products that reflect the distinguished features of the country as represented by its people, arts, history, and the physical environment. Although, there is no precise definition of the creative economy, the following features are identified with such an economy:

1. It can foster income generation, job creation, and export earnings while promoting social inclusion, cultural diversity, and human development.

\footnotetext{
${ }^{4}$ http://www.flightglobal.com/news/articles/world-airline-rankings-regional-picture-359695/.
} 
2. It embraces economic, cultural, and social aspects interacting with technology, intellectual property and tourism objectives.

3. It is a set of knowledge-based economic activities with a development dimension and cross-cutting linkages at macro and micro levels to the overall economy.

4. It is a feasible development option calling for innovative, multi-disciplinary policy responses and inter-ministerial action.

5. At the heart of the creative economy are the creative industries (Creative Economy Report, 2010, p. 10).

Table 1

Turkey: Creative Industries Trade Performance, 2002-2008 (Millions of \$)

\begin{tabular}{llll}
\hline 2002 & Exports & Imports & Balance \\
\hline All creative industries & 4,864 & 1,325 & 3,539 \\
All creative goods & 2,154 & 913 & 1,241 \\
All creative services & 2,710 & 412 & 2,298 \\
\hline
\end{tabular}

Source: United Nations: Creative Economy Report, 2010.

Table 2

Turkey: Creative Industries Trade Performance, 2008 (Millions of \$)

\begin{tabular}{llll}
\hline 2008 & Exports & Imports & Balance \\
\hline All creative industries & 6,593 & 3,758 & 2,835 \\
All creative goods & 5,369 & 3,523 & 1,846 \\
All creative services & 1,224 & 235 & 989 \\
\hline
\end{tabular}

Source: United Nations: Creative Economy Report, 2010.

Tables 1 and 2 illustrate the importance of creative industries and services in Turkey and its impact on trade performance. As the tables show, Turkey enjoys a surplus in production and exports of creative industries, creative goods, and creative services during the period 2002-2008. This reflects Turkey's rich heritage and unique culture that can be used to support the building of creative industries and creative economy.

Small and medium enterprises contribute to the development of such industries by integrating them into the creative economy through greater funding, better incentive, and skill acquisition. Domestic enterprises possess substantial amount of tacit knowledge that can be channeled into the production of creative products and attractive artistic and cultural features. Building such an economy depends largely on indigenous knowledge and local supplies of materials and services. Tourism comprises multidimensional processes of market activities that require setting up several industries and services. The spillover effects of these activities could stimulate the rest of the economy by increasing demand and inducing supply. For example, the demands for cultural products by tourists including visiting natural sites and museums contribute to the creation of new services and the expansion of domestic cultural heritages including dance, music, opera performance, publishing fashion, software, advertising, and indigenous crafts. In recent years, the rise of globalization has increased interactions among individuals, groups, and nations which in turn increased interest in traditional knowledge and culture of other groups representing the foundation of the creative industries.

Tacit knowledge could add value to the creative economy by exploiting untapped skills and artistic features stored in the mind of millions of ordinary people. Creating such opportunities promotes entrepreneurship by expanding market demand for new artistic and cultural products which can be provided by the poor with little financial requirements. 
In this era of globalization, it is expected that real income per person at the global level will increase in the coming decades which will impact foreign travel worldwide. Turkey could ratchet up investment in infrastructure that facilitates the attraction of foreign visitors to the country. Inflows of foreign visitors directly and indirect impinge on future development through linkage creation, foreign exchange earnings, employment generation, creative industries, and export potential. In promoting such an economy, the government needs to play a greater role by identifying some of the important features to support the fundamentals for building a creative economy. Effective government policies and adequate incentive regimes facilitate the establishment and implementation of creative industries and services.

\section{Tourism: The Multiplier Effects}

Expenditures by tourists represent an important component of total consumption expenditure generating in the process larger increase in GDP. In Turkey, the amount of money spent by tourists accounts for a sizable proportion of total expenditure on consumption. Tourism not only enhances linkages within the productive sectors of the economy, but also increases income through the multiplier effects. Unlike leakages which reduce the effectiveness of the multiplier, expenditures by foreign tourists generate new rounds of stimulus creating new demands for locally produced goods and services. Such demand usually encourages local producers to increase supply of these goods and services creating in the process a chain of market activities. In a highly diversified economy, expenditures by tourists allow for the establishment of new industries to support market demand created by tourism. There are both induced and indirect effects generated by the multiplier. The national economy benefits from tourism through increasing in consumer spending brought by incomes earning from foreign visitors.

The multiplier effect refers to the cumulative impact of a unit of tourism expenditure as that expenditure is re-spent in the local economy. The multiplier effect arises because induced increases from tourist spending affects consumer spending which occurs due to the increased incomes and because of the feedback into increased business revenues, jobs, and income. The multiplier describes the final change in an economy's output relative to the initial change in tourist expenditure. (United Nations, 2007, p. 48)

The impact of tourism on local socio-economic development depends on the share of tourist expenditures that do not leak outside the country. The effectiveness of the multiplier is linked to the size of the leakages which reduce the positive contribution of tourism to the local economy (United Nations, 2011).

In the case of income generated from tourism, it is autonomous or independent from income generated by the local economy. In other words, this income is not linked to the changes that occur in the economy but to external forces as in the case of expenditures by tourist. The size of these expenditures is linked not only to the number of tourists who visit the country, but also to services demanded by tourists. Theoretically, expenditures by tourists, if not leaked out, create direct and indirect effects through the multiplier. In most poor countries, because of high poverty and low income, expenditures by foreigners stimulate market activities and increase linkages. It is estimated that in Turkey the tourist multiplier accounts for 1.96 which is high compared to other countries (United Nations Environment Programme, 2011). On the opposite side of the coin, this high multiplier makes the Turkish economy vulnerable to downticks in tourism - a decline that started in 2015 and is gaining further momentum in 2016.

In a highly diversified economy, most tourist services are provided by local producers through linkages caused by large circulation of money in the domestic markets. In contrast, the leakage of larger share of tourist 
dollars through the importation of goods and service weakens the multiplier due to low demand for locally produced goods and services. Also, the effectiveness of the multiplier depends on the type of tourist and their spending patterns. Yong people are usually spending less money than older people due to their high mobility and low cost accommodation habits.

In the case of the multiplier, it is the secondary effects of tourism that generate stimulus through the creation of demand for domestic activities in the economy. Thus, multipliers are expected to be higher for economies or regions with high degree of economic diversity in which suppliers take advantage of the linkage effects of tourist spending. The diversified economy of Turkey could strengthen the spillover effects of the multiplier by expanding local facilities and services needed for serving tourists. In addition, the diversity of tourist services increases the potential for the creation of large linkage effects within the domestic economy. To this end, the government should ensure that adequate investment is allocated for the tourist industry that encourages local suppliers and services providers to provide the necessary services for tourists. The economic impact of tourism can be estimated as follows:

Economic impact $=$ Number of tourists $*$ Average spending per person $*$ Multiplier.

In addition to the income increase produced by the multiplier, tourism also creates linkages which positively affect the level of income in the economy. Linkages usually occur from the connection between various activities of tourism and domestic suppliers of goods and service. There is wide range of business activities involved with tourism which are seen by local producers and serve provider as the supply chain. In a developing country, these linkages can stimulate development by increasing the supply of goods and services related to tourism. The demand by tourists for goods and services encourages local suppliers to produce these goods locally instead of importing them. Not only such newly created activities foster productivity and diversify the economic structure, but also improve the country balance of payments position. In this regard, local firms need to gain competitive advantages through knowledge creation, skills development, creative investment and innovation. Table 3 illustrates some of the important linkages associated with tourism.

Table 3

\section{Examples of Supply Chain Linkages Within Selected Sectors of the Tourism Industry}

\begin{tabular}{|c|c|}
\hline Hotel companies & $\begin{array}{l}\text { - construction materials, such as wood, stone, straw for thatching and locally made mud } \\
\text { bricks, giving a local style to the hotels and could enhance their attractiveness } \\
\text { - furniture made of local wood varieties, provided its exploitation is environmentally } \\
\text { sustainable } \\
\text { - carpets and rugs, locally woven by traditional craftsmen and women } \\
\text { - decorative objects designed, painted, and/or produced by local artists } \\
\text { - bed linen, tablecloths, napkins, and other textile items, which need frequent replacement } \\
\text { - food items, especially fresh produce grown by local farmers, but also some processed items } \\
\text { such as juices, bread, etc. } \\
\text { - laundry services, especially to replace expensive, often imported washing and/or drying } \\
\text { equipment in small and medium-sized accommodation establishments }\end{array}$ \\
\hline $\begin{array}{l}\text { Restaurants and other } \\
\text { catering establishments }\end{array}$ & $\begin{array}{l}\text { - furniture, tablecloths, decorative objects, etc., as listed above } \\
\text { - local food items, especially fresh produce grown by local farmers } \\
\text { - local drinks, freshly-produced juices, etc. } \\
\text { - local dishes, reflecting the local gastronomy }\end{array}$ \\
\hline $\begin{array}{l}\text { Tour operating } \\
\text { companies }\end{array}$ & $\begin{array}{l}- \text { local guides } \\
\text { - local, traditional means of transport } \\
\text { - local cultural attractions and traditional ceremonies }\end{array}$ \\
\hline
\end{tabular}

Source: Eugenio Yunis, "Poverty-Sensitive Value Chains in the Tourism Industry" (Madrid: UNWTO, October 2006, p. 49), United Nations, Study on the Role of Tourism in Socio-Economic Development (New York: United Nations, 2007). 
In modern economies, technology is a powerful tool for enhancing productivity and accelerating the process of structural change. Thus, technological creativity is vital for the development of the economy which is greatly influenced by the society scientific, cultural, and economic features. These features represent dynamic process that involves imagination, motivation for creation of new things, and the desire to develop new ideas which lead to the development of new technologies, new products, and new methods. In this respect, creativity is about generating new ideas that enhance innovation, business practices, marketing and production. In the case of tourism, creative industries and services represent wide range of market activities dealing with large sectors of the economy. Products of creative ideas are important components of touristic demand.

Konya could cash on the tourist industry by making efforts to promote its historical and religious heritage as center for spiritual and cultural activities. ICTs have helped in connecting with potential customers by allowing commercial and government institutions to advertise and run campaigns for attracting foreign tourists. Thus, tourism must be integrated into the long term government planning policies to ensure that the government is supporting the initiatives for building adequate facilities to make the city attractive for tourists.

\section{Contribution of Tourism to Development}

Tourism contributes in a variety of ways to economic development. In addition to job creation and income earnings, tourism contributes to the construction of infrastructure, raises awareness about diseases including HIV, protects the environment, stimulates transportation, increases government revenues, enhances internal and external trade, promotes understanding, and accelerates rapid socio-economic transformation. In most developing countries, poverty remains among the important challenges facing policy makers. Opening up the country through programs and services to attract foreign tourist provides new opportunities, especially for youth, women, the poor, and the unemployed. In regions where government services are not adequately provided, tourism encourages economic diversification and stimulates linkages. These linkages could increase integration among various sectors of the economy including those directly related to tourism such as food, crafts, transportation, energy, and construction.

Isolated regions with weak linkages creation usually encourage income earned from foreign visitors to leak out searching for new opportunities outside the local economy. Thus, benefits from tourist income will require increasing capital expenditure in the local economy to encourage domestic suppliers providing locally produced products and services. Local producers, due to geographical barriers, are at a disadvantage in the supply goods and services with good quality at competitive prices.

Governments are required to adapt policies and provide facilities including financial credits, marketing skills, physical infrastructure as well as access to ICT and modern digital services in order to support local suppliers and encourage domestic production. Providing such facilities will encourage income earned from tourist visitors to be invested in the local economy instead of being leaked outside the region. Furthermore, local ownership of businesses related to tourism is important for keeping revenues inside the local economy instead of having these revenues leaked out as in the case of foreign ownership. A poor country with little investment capital is likely to lose a substantial amount of its revenues from tourism to foreign capitalists. In addition, these countries spend substantial amount of foreign exchange earnings on imported goods and services needed to support the tourist industry. Under such circumstances, local investment becomes vital for creating linkages.

In the case of Konya, religious and spiritual tourism could become more attractive if the local government 
undertakes measures to improve the quality of services provided for foreign visitors. These services could include festivals commemorating the religious teaching and musical folklores of his Sufi practices. The money these tourists spend will generate a wide range of market activities including linkages that benefit large segment of the economy. Tourism creates not only demand for unskilled labor, especially women, but also demand for locally produced products including food and cultural goods. In cases such as these, investment in the tourist sector provides new opportunities for microenterprises. In other words, tourism fosters the mobilization of domestic resources to strengthen the economic fundamentals including building infrastructures, increasing demand for services, and stimulating agricultural production. Local governments stand to benefit fiscally by increases in tax collections essential for diversifying the domestic economy and creating new investment and employment opportunities for local enterprises.

Tourism increases integration among various sectors of the economy through backward and forward linkages. Due to the fact the Turkish economy is highly diversified, financial leakages are not likely to be problematic for the economy. Most investment in the local economy is locally made by local enterprises reflecting the fact that earnings from the tourist sector are most likely to remain within the economy. In other words, most of the services provided by hotels, transportation, food, and tour guides are produced in the domestic economy.

\section{Conclusion}

Tourism has been widely discussed in the literature on economic development, reflecting the linkage effects that this sector could generate impacting the overall performance of the economy. In recent decades, rapid globalization and improvement in communication and transportation technologies, combined with increases in disposable income per capita, has increased demand for tourism. In particular, countries boasting attractive geographies and historical sites possess potential to benefit from the tourist sector through job creation, foreign exchange inflows, creative products, linkage effects, and income stimulus. As an important destination for tourists, Turkey provides a wide range of touristic services leveraging an infrastructure that should be expanded to induce sustained growth in the number of foreign tourists visiting Turkey on a year-on-year basis. Owing to political events, however, the number of tourists visiting Turkey, peaking in 2014, started to decline in 2015 (either the decline in tourists from Russia) continuing at an accelerating pace in 2016 with intendent consequences on the economy from a de-multiplier effect.

In the short run, owing to political events, Turkey's tourism sector will experience decline not withstanding any increased investment in infrastructure, communication, and accommodation that serves to increase the country's capacity to create linkages that induce demand for goods and services provided by local producers. Acts of terrorism and the refugee crisis are likely to take a significant toll on Turkish tourism in the future so, more than ever, given its important role in contributing to the economy and its potential impact on future development, tourism should be integrated into the national security policy as well as national economic policy to ensure that current decline in this sector is stemmed and reversed in order to meet goals set in the national development plan.

\section{References}

Akal, M. (Spring 2010). Economic implications of international tourism on Turkish economy. International Multidisciplinary Journal of Tourism, 5(1), 131-152.

$\begin{array}{llllll}\text { ASIA Times } & \text { News. } & \text { (February } & 25, & \text { 2016). } & \text { Retrieved from }\end{array}$ 
http://atimes.com/2016/02/tough-times-ahead-for-turkeys-tourism-industry/

Corpo, B. D., Gasparino, U., Bellini, E., \& Malizia, W. (2008). Effects tourism upon the economy of small and medium-sized

European cities: Cultural tourisms and the others. Retrieved from http://papers.ssrn.com/sol3/papers.cfm?abstract_id=1140611

Candela, G., \& Figini, P. (2010). The economics of tourism destinations. Bologna: McGraw-Hill.

Lejarraja, I., \& Walkenhhorst, P. (2007). Diversification by deepening linkages with tourism. Washington: World Bank.

Mazumder, M. N. H., Al-Mamun, A., Al-Amin, A. Q., \& Mohiuddin, M. (2012). Economic impact of tourism-a review of literatures on methodologies and their uses: 1969-2011. Retrieved from http://www.intechopen.com/books/visions-for-global-tourism-industry-creating-and-sustaining-competitive-strategies/econo mic-impact-of-tourism-a-review-of-literatures-on-methodologies-and-their-uses-1969-2009

OECD. (2016). OECD tourism trends and policies 2016. Paris: OECD Publishing. Retrieved from http://dx.doi.org/10.1787/tour-2016-en

Republic of Turkey. (January 2010). Turkish tourism industry report. Deloitte.

United Nations. (2007). Study on the role of tourism in socio-economic development. New York: United Nations.

United Nations. (2010). Creative economy report 2010. New York: United Nations.

Unite Nations Environment Programme. (2011). Tourism: Investing in energy and resource efficiency. New York: United Nations.

World Economic Forum. (2015). The travel and tourism competitiveness report 2015. Geneva: World Economic Forum.

World Tourism Organization. (15 April 2015). PR No. 15029. Retrieved from http://media.unwto.org/press-release/2015-04-15/exports-international-tourism-rise-us-15-trillion-2014

World Travel \& Tourism Council (WTTC). (2015). Economic impact 2015. Retrieved from https://www.wttc.org/-/media/files/reports/economic\%20impact\%20research/regional\%202015/world2015.pdf 